\title{
Westward Extension of the Okinawa Trough at its Western End in the Northern Taiwan Area: Bathymetric and Seismological Evidence
}

\author{
Chengsung Wang ${ }^{1}{ }^{*}$, Min-Lang Yang ${ }^{1}$, Chi-Ping Chou ${ }^{1}$, Yet-Chung Chang ${ }^{2}$ and Chao-Shing Lee ${ }^{1}$
}

(Manuscript received 27 September 1999, in final form 11 January 2000)

\begin{abstract}
In this paper, we used detailed bathymetry, earthquake distribution and focal mechanisms to study the phenomenon of active westward extension of the Okinawa trough in the northern Taiwan area. We found a distinguishable subsiding and collapsing area on the continental shelf edge and the continental slope on the northern side of the Okinawa trough. This area extends westwards to at least $121.5^{\circ} \mathrm{E}$ and includes several morphological units related to the existence and formation of three major canyons. The canyons and the morphological units are still evolving through the sediment transport and through the subsidence and collapse of material due to the formation of the Okinawa trough. According to the degree of development, we found that these morphological units have developed from the east to the west. There are two parallel E-W trending central graben at the westernmost part of the Okinawa trough, with each corresponding to a narrow shallow seismic belt. The widths of the central graben are 10-15 $\mathrm{km}$. There is geophysical and geological evidence that the formation of these central graben has been extended westwards to the onland area of Taiwan. Focal mechanisms of earthquakes and the topographic features show that the formation of the Okinawa trough is associated with the down-dip extensional stress along the subducting slab of the Philippine Sea plate, and most of northern Taiwan and all the northeastern offshore area of Taiwan are under tensional stress. New portions of the Okinawa trough have been forming across the whole width at its western end through subsidence in the continental shelf, the continental slope and the traditionally recognized area of the Okinawa trough in the northeastern Taiwan area, to make the Okinawa trough develop gradually and extend westwards.
\end{abstract}

(Key words: Development of the Okinawa trough, Detailed bathymetry,

\footnotetext{
${ }^{1}$ Institute of Applied Geophysics, National Taiwan Ocean University, Keelung, Taiwan

${ }^{2}$ Tainan Hydraulics Laboratory, National Cheng Kung University, Tainan, Taiwan

* Corresponding author address: Prof. Chengsung Wang, Institute of Applied Geophysics, National

Taiwan Ocean University, \#2 Pei-Ning Rd., Keelung, 202 Taiwan

E-mail: wangcs@mail.ntou.edu.tw
} 


\section{Earthquake distribution, Focal mechanisms)}

\section{INTRODUCTION}

The Okinawa trough (Fig. 1) lying on the northwestern side of the Ryukyu arc extends about one thousand kilometers from southwestern Kyushu in Japan to northeastern Taiwan. It is the backarc basin of the Ryukyu subduction zone (e.g., Lee et al., 1980; Sibuet et al., 1998), which is caused by the northwestern subduction of the Philippine Sea plate beneath the Eurasian plate of the East China Sea along the Ryukyu trench. In general, the Okinawa trough runs in the NE-SW direction. Its trend changes from the NE-SW to the E-W direction in its southwestem part. It shoals and narrows down westwards near Taiwan and seems to terminate at the eastern slope of Taiwan (Figs. 1 and 2). This shape of topography at the western end of

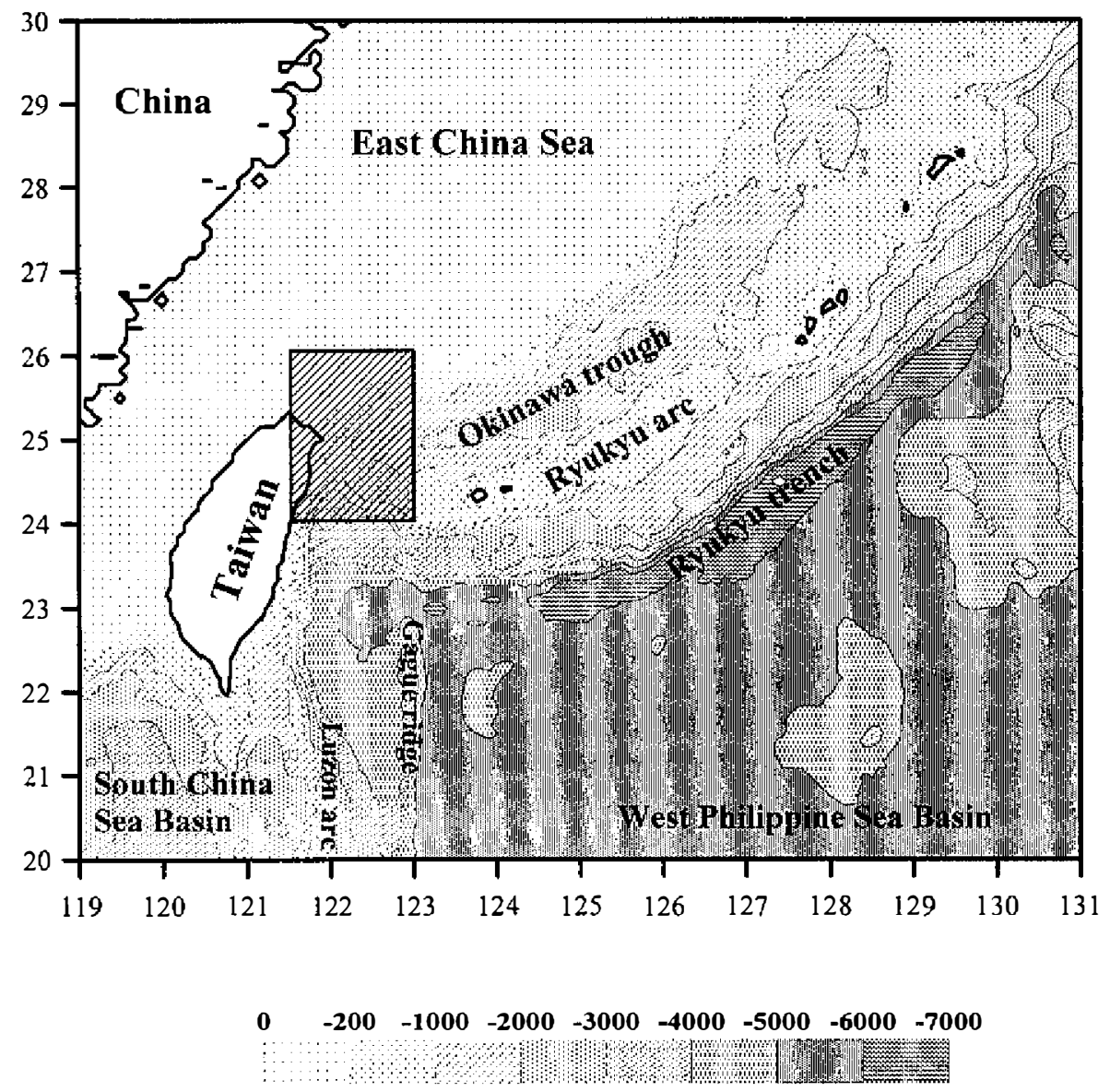

Fig. . The study area of this paper (box in the northern Taiwan area), with the bathymetry and tectonic units around Taiwan and in the Ryukyu subduction zone as background. 
the Okinawa trough leads people to believe that the Okinawa trough opens at its axial center of topography to the east of the Ilan plain (Fig. 2) in northeastern Taiwan, then is spread out to become full scale (e.g., Lee et al., 1980). So, when previous researchers (e.g., Bowin et al., 1978; Yeh et al., 1989; Liu, 1995; Yu and Tsai, 1979) discussed the western extension of the Okinawa trough in the northern Taiwan area, they considered only the axial extension of the trough to the Ilan plain. However, on analyzing the bathymetric and seismological data recently, we found that, in the northern Taiwan area at and near the western end of the Okinawa trough, there are special features in the morphology and seismicity which indicate that new portions of the Okinawa trough have been forming along the whole width at its western end through subsidence and collapse of material in the continental shelf edge and the continental slope and through development of E-W trending graben near the axial center of the trough. In this paper, we shall describe these morphological and seismological features as evidence of the westward extension of the Okinawa trough at its western end.

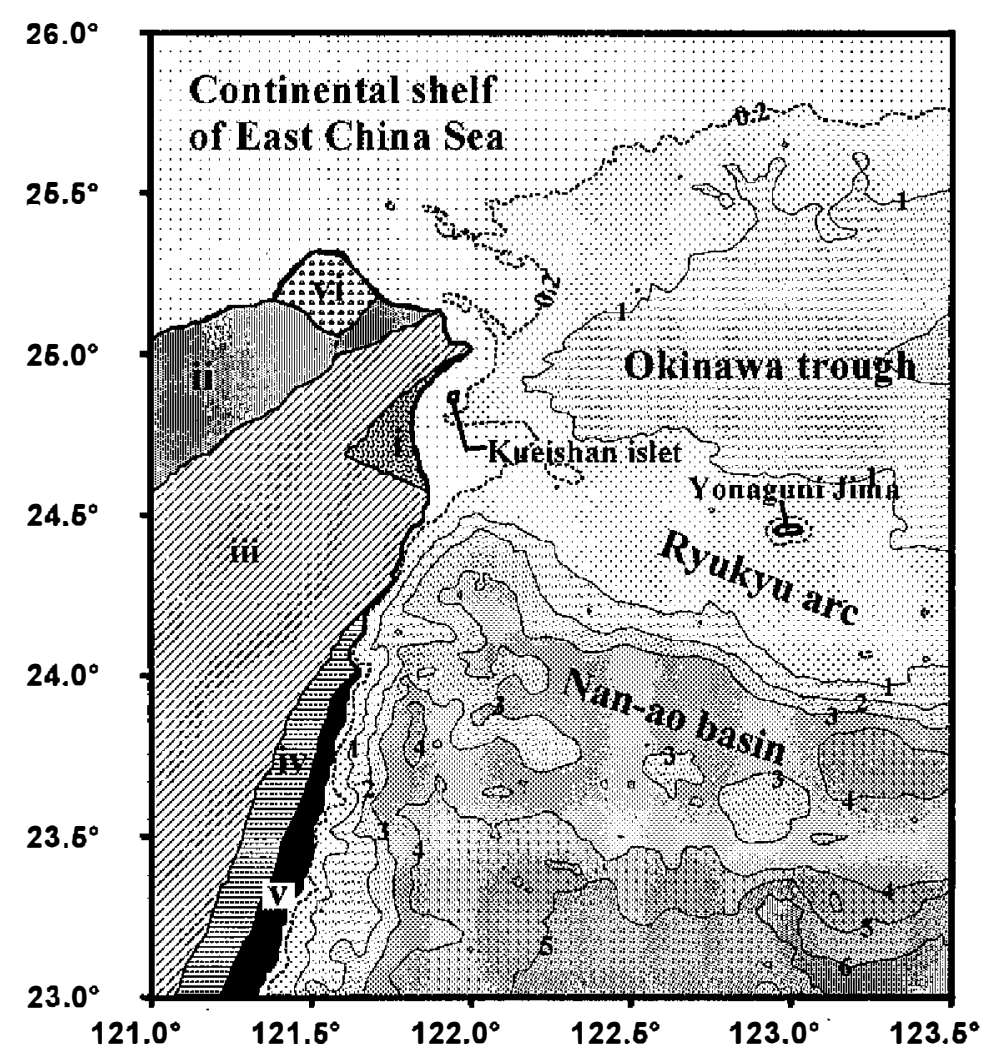

Fig. 2. Structural provinces on the Taiwan island (simplified from Ho, 1988) and its northeastern offshore area, to facilitate the discussion in the paper. The bathymetric data are taken from Liu et al. (1996). i: Ilan plain; ii: West Foothills; iii: Central Range; iv: Longitudinal Valley; v: Coastal Range; vi: Tatun Volcano. 


\section{MORPHOLOGY}

\subsection{Bathymetric Data}

Enough bathymetric data have been collected during the past few years to compile a detailed bathymetric map for analyzing the morphological features in the northeastern offshore area of Taiwan. Figure 3 shows the cruise lines of research vessels equipped with Global Positioning System and the traditional echo-sounder which carried out different research missions in the study area during the period 1990-1996. The bathymetric data collected along these cruise lines are used to compile a bathymetric map with grid spacing of 180 meters. These bathymetric data were mostly collected by R/V Researcher I and R/V Researcher II, operated separately by National Taiwan University and National Taiwan Ocean University. It can be seen that the cruise lines are dense and well distributed, and thus can reflect the detailed

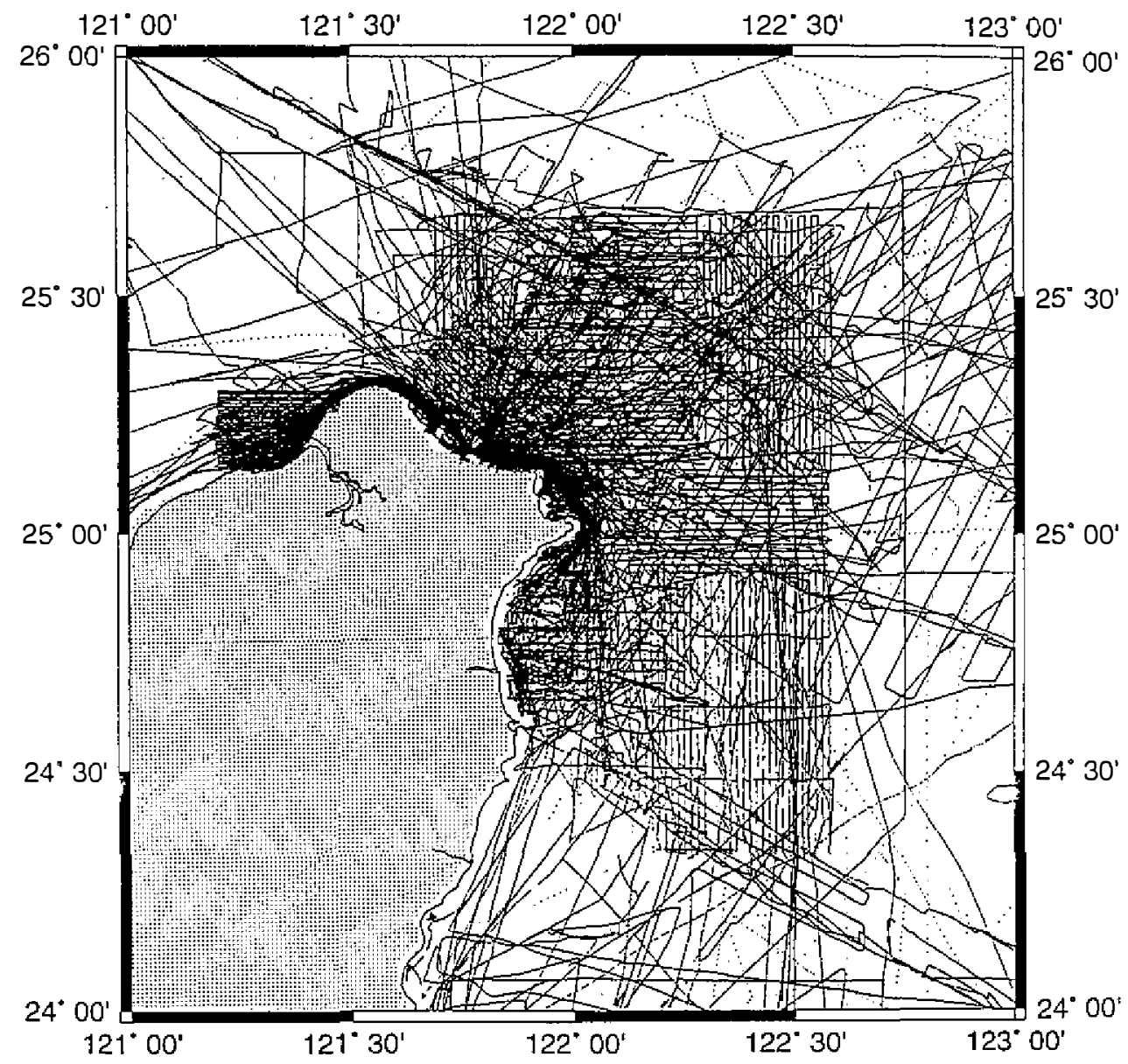

Fig. 3. Cruise lines of research vessels for the period 1990-1996 along which the bathymetric data were used for mapping the bathymetry used in this study. 
bathymetry in this area reasonably well. In 1996, a French-Taiwanese cooperative research program (the Active Collision in Taiwan program) was carried out aboard French R/V L'Atalante in the offshore areas of Taiwan (Lallemand et al., 1996). Shown in Fig. 4 are the ACT cruise lines in the western Okinawa trough, along which the bathymeric data were collected by the multibeam echo-sounder, together with gravity and magnetic data. These cruise lines are mainly in the deep water area with water depths greater than 1,000 meters. Since the cruise lines were designed for good coverage of the Okinawa trough, the bathymetry compiled from these data therefore has better resolution than those compiled from data along the cruise lines shown in Fig. 3. In order to obtain a bathymetric map which maintains the best resolution in the two data compilations, we combined the compiled bathymetric data sets from the two compilations by using the multibean data where they are available. Figure 5 show the bathymetry in the northeastern offshore area of Taiwan compiled in this way.

\subsection{Canyons and Morphological Units on the Continental Shelf/Slope}

It can be seen from Fig. 5 that the topography of the continental shelf edge and the conti-

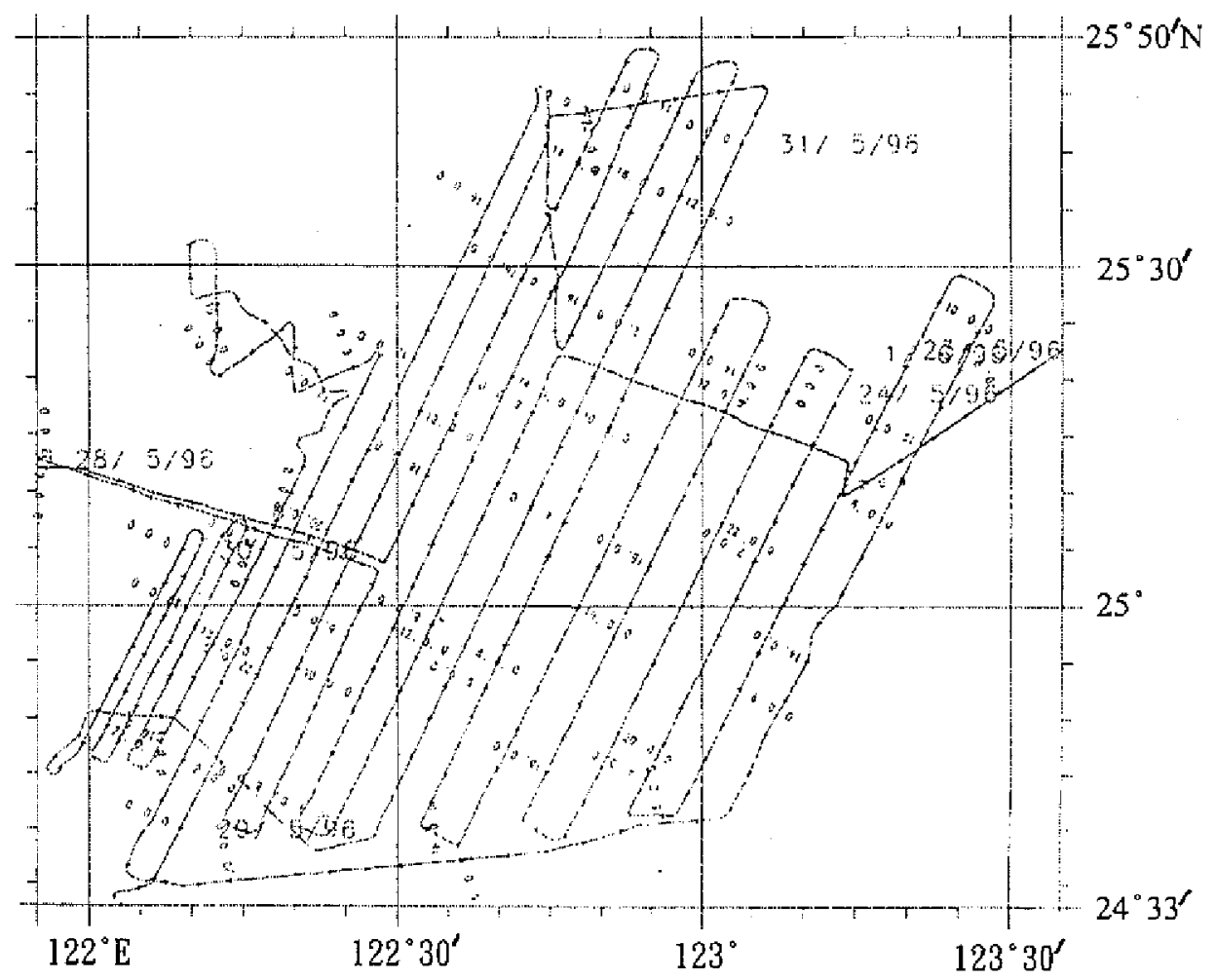

Fig. 4. Cruise lines of French R/V L'Atalante in 1996 in the westernmost part of the Okinawa trough (Lallemand et al., 1996). The cruise lines were designed to have a good coverage of the sea floor by the multi-bean echo sounder. 
nental slope of the East China Sea is complicated by the cutting of submarine canyons. There are three major canyons in the continental shelf-slope area. They are the Chilung Valley, the Mien-hua Canyon and the North Mien-hua Canyon (Fig. 5), named and described by Yu (1992), Song and Chang (1993) and Yu and Shyu (1994). These canyons are interpreted as rightlateral strike-slip faults by Hsu et al. (1996). Associated with the development of these three canyons, the continental shelf-slope area can be divided into five different morphological units (Fig. 5): the Mien-hua Drainage Basin, the North Mien-hua Drainage Basin, the Mien-hua Slope, the Chilung Shelf and the Chilung Slope.

The Mien-hua Drainage Basin is related to the Mien-hua Canyon and its western tributary in the west, which run in a NW-SE direction. It has the shape of elongated triangle. The North Mien-hua Drainage Basin is related to the North Mien-hua Canyon. It has the shape of an inverted regular triangle, with four main ributary canyons excavated by the collapse and transportation of sediments. The Mien-hua Slope is the part of continental slope between the Mienhua Canyon and the North Mien-hua Canyon. It is a gradual slope connecting a narrow subsided terrace under an inner slope (the northern border of the Mien-hua Drainage Basin; Fig. 5; and Song et al., 1997). The Chilung Shelf is a subsided part of the continental shelf of the East China Sea (Song et al., 1997), bordered by the Chilung Valley and the Mien-hua Canyon and its western tributary. It is lower than the rest of the continental shelf of East China Sea and generally tilts to the southeast (Fig. 5). Seismic reflection profiles show that there are normal faults cutting through the top sedimentary layers of this part of the subsided continental shelf (e.g., Huang et al., 1992; Teng, 1998; Song et al., 1997). The Chilung Slope is the part of the continental slope between the Mien-hua Canyon and the Ilan plain in northeastern Taiwan, and borders the Chilung Shelf on its southeast side.

We compared the canyons, the drainage basins and the slopes in Fig. 5, and found some interesting features. Morphologically, the North Mien-hua Drainage Basin has been developed to a much higher degree than the Mien-hua Drainage Basin; the North Mien-hua Canyon and the tributary canyons in the North Mien-hua Drainage Basin are deeper and clearer than the Mien-hua Canyon and the tributary canyons in the Mien-hua Drainage Basin (See Song et al., 1997, and Yu and Lee, 1998, for the detailed morphological description of these canyons). The Chilung Valley is the shallowest of the three canyons in the continental shelf-slope area. A clear drainage basin has not yet developed with the Chilung Valley. According to the degree of development, the North Mien-hua Drainage Basin should be older than the Mien-hua Drainage Basin. The North Mien-hua Canyon should have been formed first , and then Mien-hua Canyon. The Chilung Valley should be the newest of the three canyons. The Mien-hua Slope is a gradual slope, compared with the Chilung Slope (See Song et al., 1997, for a detailed description and comparison of these two slopes). The latter is still a border of a subsided terrace of the continental shelf (Chilung Shelf), while the former should have developed by collapse and slump of material on a subsided terrace. It is therefore believed that the Mien-hua Slope has been eroded and has slumped more seriously and for a longer time than the Chilung Slope. From the above analysis of the morphological features in the continental shelf-slope area to the northeast of Taiwan, we conclude that these morphological features must have different degrees of development, with the eastern features having a higher degree of development than the western features. This implies that, near the western end of the Ryukyu subduction zone, 


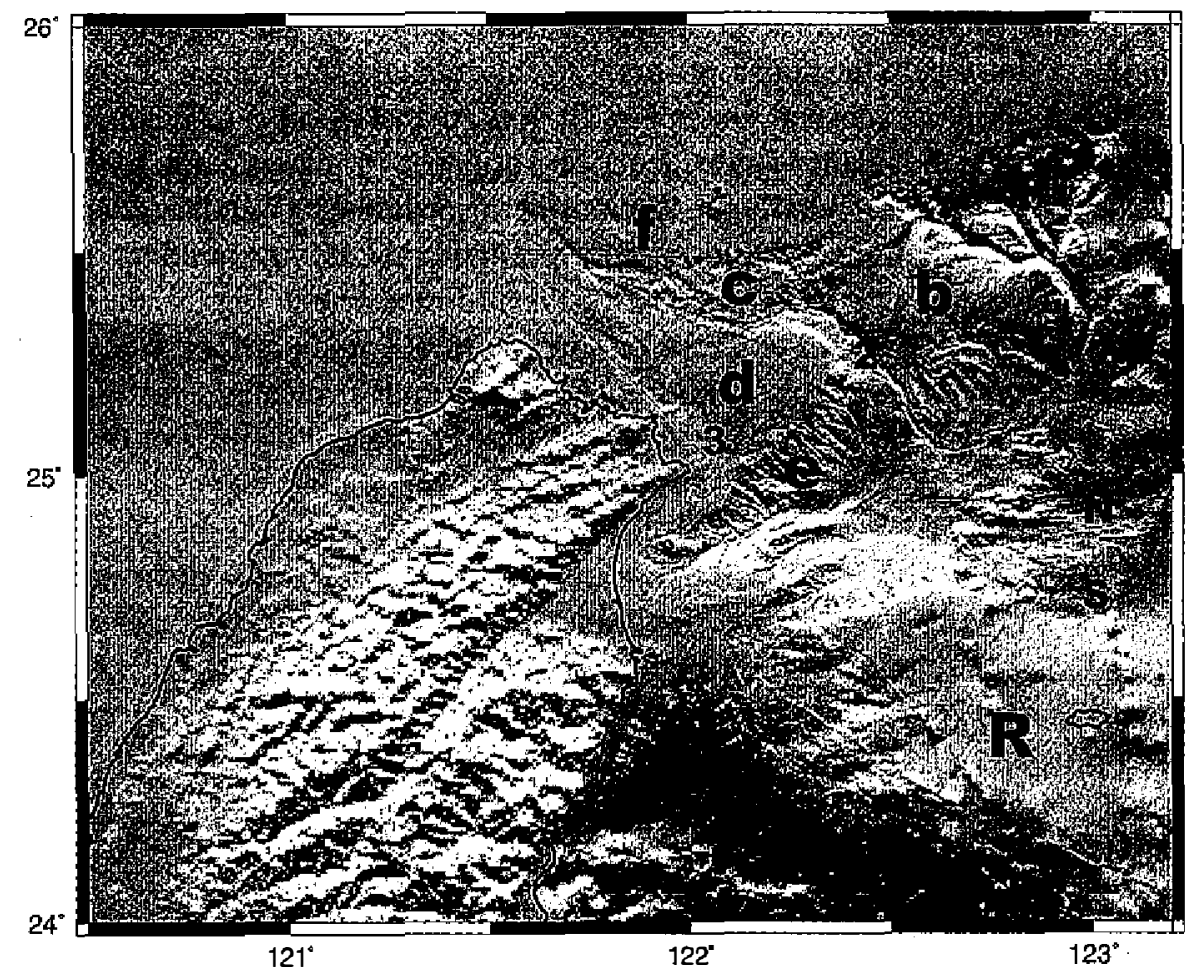

Fig. 5. Morphological map of the northeastern area of Taiwan. a: North Mienhua Drainage Basin; b: Mien-hua Slope; c: Mien-hua Drainage Basin; d: Chilung Shelf; e: Chilung Slope; f: area for future collapsing; N: northern central graben in the deepest part of Okinawa trough; S: southern central graben; R: Ryukyu arc; 1: North Mien-hua Canyon; 2: Mien-hua Canyon; 3: Chilung Valley.

the Okinawa trough must have a higher degree of morphological development in its eastern portion than in its western portion and that the Okinawa trough must have been developing and extending from the east to the west.

\subsection{Area of Subsidence on the Continental Shelf/Slope}

From Figs. 1, 2 and 5, we can see that the raditionally-defined Okinawa trough becomes narrower and shoals westwards and seems to terminate against the eastern slope of the Ilan plain in northeastern Taiwan. However, there is an elongated triangle of low land (with boundaries indicated by dashed lines in Fig. 5) which lies on the continental shelf-slope area of the East China Sea to the north of the Okinawa trough and protrudes westwards in parallel with the Okinawa trough. This triangle of low land extends to about $121.5^{\circ} \mathrm{E}$ in the northern offshore area of Taiwan (to the north of the Tatun Volcano in northern Taiwan), and includes the North Mien-hua Drainage Basin, the Mien-hua Slope, the Mien-hua Drainage Basin and the 
Chilung Shelf. This triangle is bordered by the Chilung Valley in the west and a subsidence boundary in the north (where the apparent slumping, sliding and subsidence of material on the continental shelf-slope stops; dashed line in Fig. 5). It is an area of subsidence on the continental shelf-slope, which is the result of subsidence and collapse of material due to the extension of the western end of the Okinawa trough. The northern subsidence boundary (the dashed line in Fig. 5) borders the two drainage basins at different latitudes. If we extend the north border line of the North Mien-hua Drainage Basin to the west (dotted line in Fig. 5), then it defines a subarea (Subarea $f$ ) which would collapse or subside to become parts of the two drainage basins in the near future. There are several Pliocene-Quaternary volcanic islets situated in the area of subsidence and Subarea $f$, and these are attributed to partial melting of the mantle and post-collisional lithospheric extension in the northem Taiwan area (Wang et al., 1999). Figure 6 shows the $\mathrm{N}-\mathrm{S}$ directional bathymetric profiles near the western end of the Okinawa trough. If we redefine the tectonic unit of the Okinawa trough to include the area of subsidence in the continental shelf-slope and Subarea $\mathrm{f}$ shown in Figs. 5 and 6, then it can be seen that the Okinawa trough has more or less uniform width for the whole length near the western end of the Ryukyu subduction zone. This is a condition that should be taken into account in a study of the formation process of the backarc basin.

\subsection{Central Graben of the Okinawa Trough}

From Fig. 5, it can been seen that there are two obvious parallel graben trending E-W in the axially central area of the western part of the Okinawa trough. The northern graben is situated between $24.85^{\circ}$ and $24.9^{\circ} \mathrm{N}$ (designated by $\mathrm{N}$ in Fig. 5), and the southern graben between $24.7^{\circ}$ and $24.8^{\circ} \mathrm{N}$ (designated by $\mathrm{S}$ ). There is a linear chain of sparse volcanoes rending E-W and lying along the northern graben. Near the center of this graben at about $122.75^{\circ} \mathrm{E}$ there are short E-W trending chains of clustered volcanoes which are arranged almost parallel such that together all the clustered volcanoes look like a mountain range trending NE-SW. This range separates the northern graben into two halves. Morphologically the eastern half is better developed than the western half because the western half cannot yet be seen clearly. However, there are tremendous thermal activities (Tsai et al., 1998) and frequent earthquakes (see description in the next section of this paper) along this western half of the northern graben. The southem graben can only be clearly seen to the east of $122.8^{\circ} \mathrm{E}$. This graben is not as well developed as the northern graben because the former is shallower and is not as clear in shape as the latter. To the west of $122.8^{\circ} \mathrm{E}$, the shape of the southern graben disappears because of the presence of the Ryukyu arc. However, a narrow E-W trending belt of dense shallow earthquakes (see description in the next section of this paper) to the west of $122.6^{\circ} \mathrm{E}$ shows that this southern graben has been developing intensely beneath the Ryukyu arc. Figure 7 shows bathymetric profiles for tracing the westward extension of the northern and southern central graben in the northeastern offshore and onland areas of Taiwan. Although the topography is sometimes contaminated by volcanoes (e.g., profile G), the northern graben is distinct in almost every profile, and can easily be raced westwards to the onland area of Taiwan. The topography of the southern graben is seriously contaminated by the western end of the Ryukyu arc, but it is still distinguishable from the complicated topographic background. This graben 


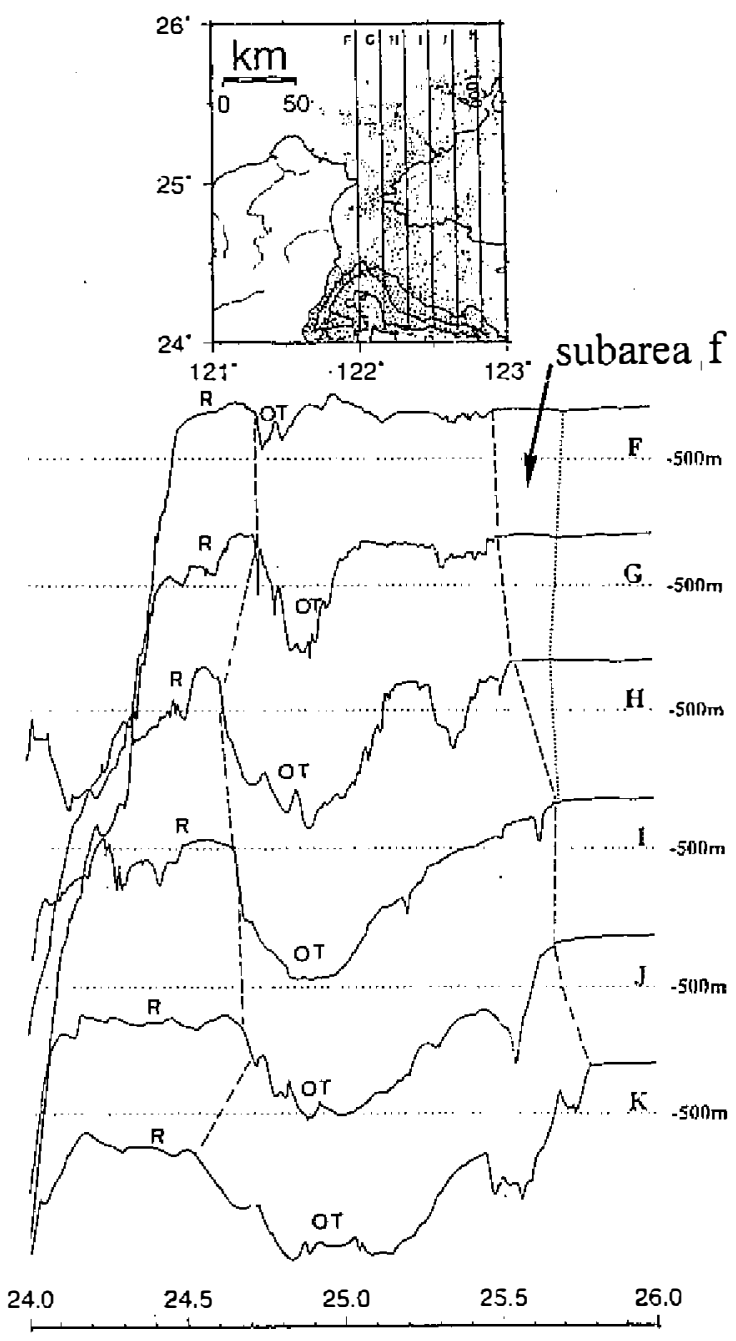

Fig. 6. The bathymetric profiles in the $\mathrm{N}-\mathrm{S}$ direction near the western end of the Okinawa trough. R: Ryukyu ridge; OT: traditionally recognized Okinawa trough; Dashed lines: distinquishabe boundary lines of the Okinawa trough; Dotted line: northern boundary line of subarea $\mathrm{f}$ (see text for explanation).

passes through the Ilan plain in northeastern Taiwan (profile $\mathrm{C}$ in Fig. 7), where a large E-W trending magnetic anomaly was found by Yu and Tsai (1979) and a crustal subsidence of 2 $\mathrm{cm} / \mathrm{y}$ was measured (Liu, 1995) in the center of the plain.

Judging from the shape of the western end of the Okinawa trough and the degree of development of the central graben discussed above, we can conclude that the two central graben must have been developing gradually from the east to the west.

\section{SEISMICITY}

The Taiwan Telemetered Seismographical Network (TTSN; formerly operated by Institute of Earth Sciences, Academia Sinica, Taipei, Taiwan) was incorporated in 1990 into the Central Weather Bureau Seismological Net work (CWBSN; operated by the Seismological 

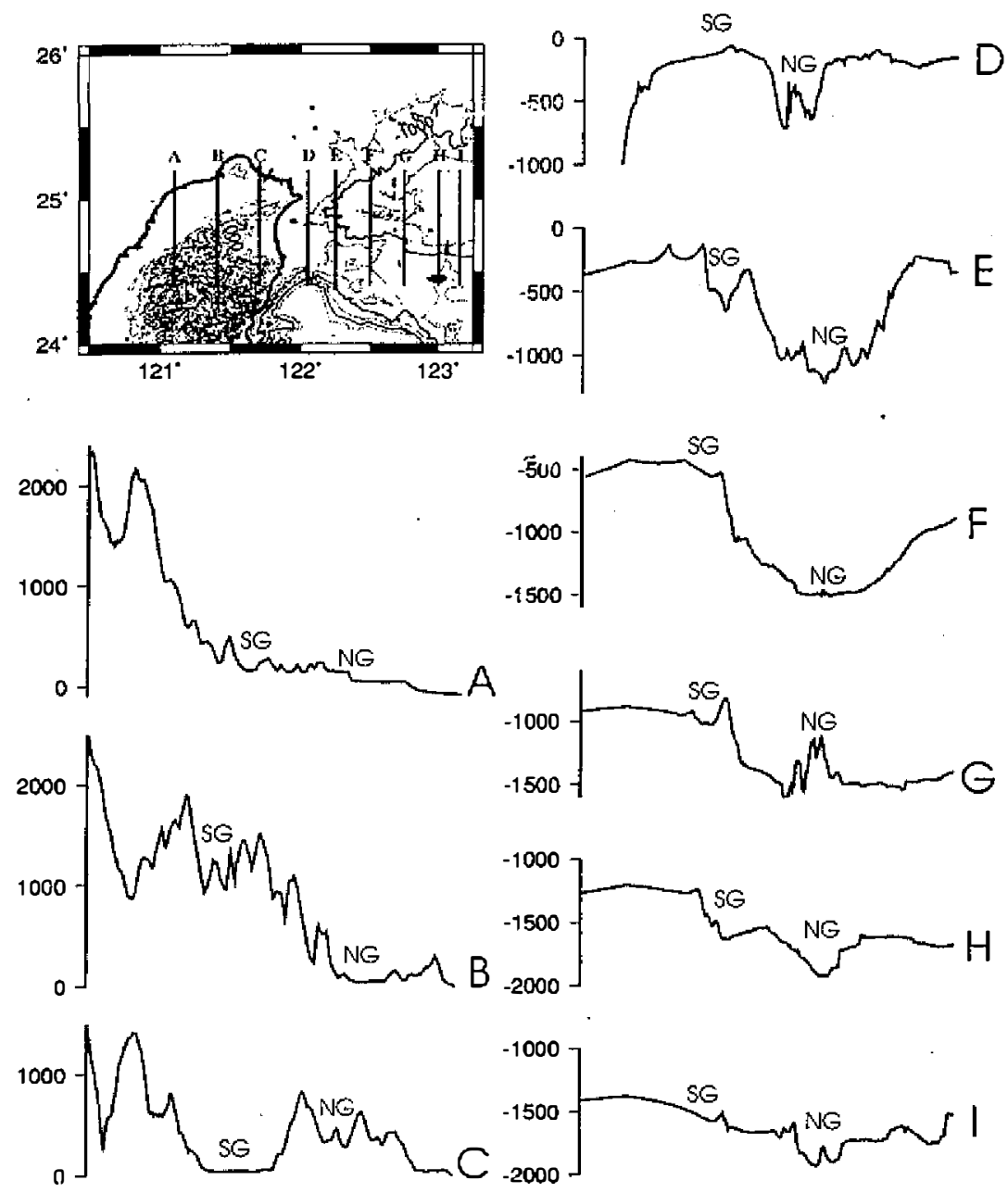

Fig. 7. The morphological profiles in the N-S direction in the northern offshore and onland areas of Taiwan for tracing the westward extension of the central grabens of the Okinawa trough. NG: northern graben; SG: southern graben.

Observation Center, Central Weather Bureau, Ministry of Transportation, Taipei, Taiwan) to be a modern earthquake monitoring network with more than seventy seismographs deployed almost evenly all over the island of Taiwan. At the same time, the earthquake recording and locating hardware and software were upgraded to improve the dynamic range of the monitoring capability and precision of earthquake location in the Taiwan region. In this section, we use the hypocentral data obtained by the CWBSN since 1991 and earthquake mechanisms from the literature to study the tectonic structure and the stress status in the westernmost part of the Ryukyu subduction zone for the behavior of the westward extension of the Okinawa trough at its western end. 


\subsection{Epicentral Distribution}

Figure 8 shows the distribution of earthquake epicenters in the northeastern Taiwan area. It can be seen that most earthquakes occur in three distinct seismic zones: the Okinawa Trough Seismic Zone, the Nan-ao Basin Seismic Zone and the Northeastern Coast Seismic Zone (Wang et al., 1994). All three of these seismic zones have their own tectonic implications. Kao et al. (1998) referred to the Nan-ao Basin Seismic Zone and the Northeastern Coast Seismic Zone as the Interface Seismic Zone and the Collision Seismic Zone, respectively, according to the different stress types shown in the focal mechanisms of earthquakes. Here, we shall concentrate our attention on the Okinawa Trough Seismic Zone.

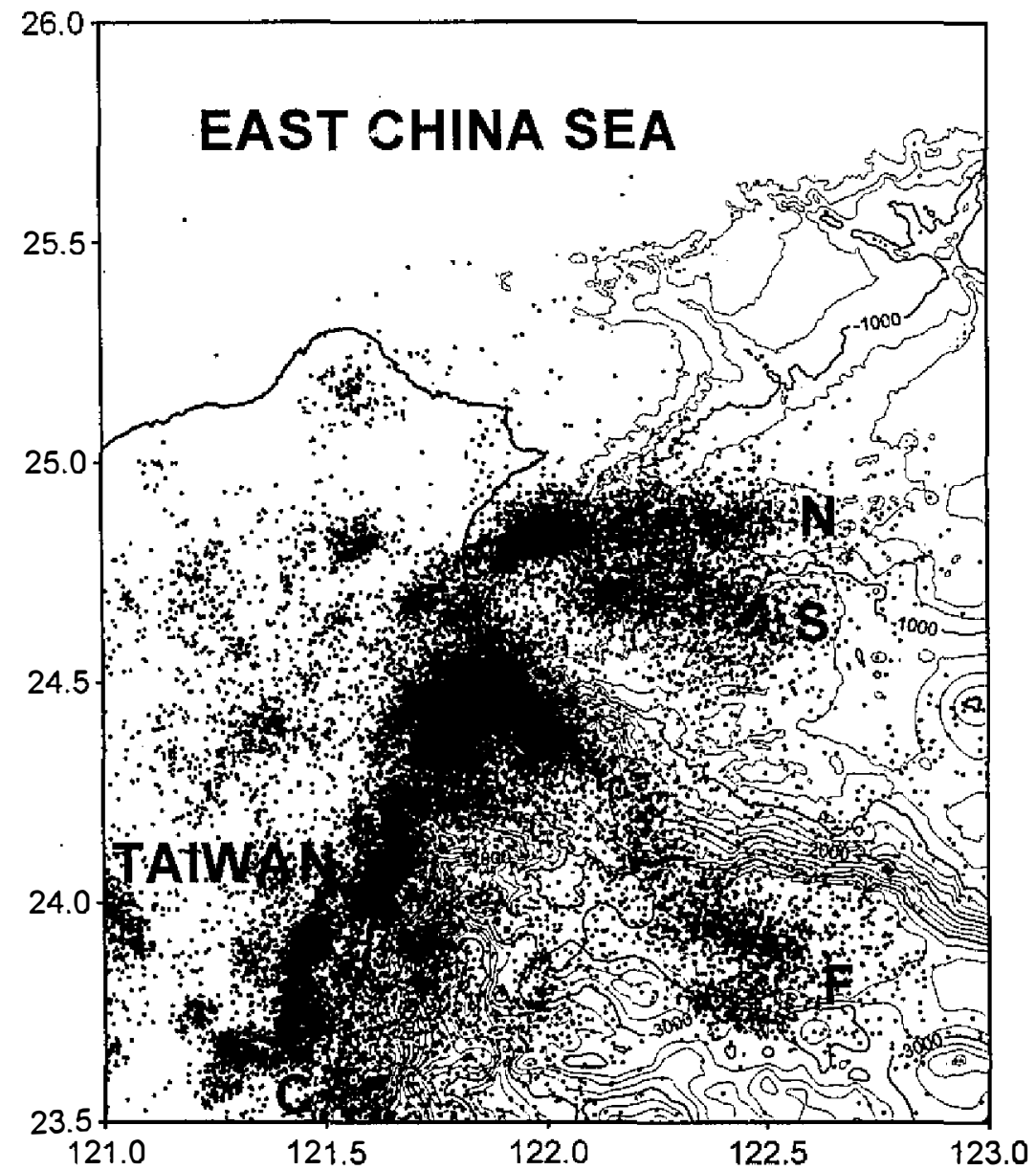

Fig. 8. Distribution of earthquake epicenters in the northeastern area of Taiwan with the bathymetric background of contour spacing of 250 meters. The Okinawa Trough Seismic Zone is divided into two E-W trending seismic belts designated by $\mathrm{N}$ and $\mathrm{S}$. The Nan-ao Basin Seismic Belt and Northeastern Coast Seismic Zone are designated by F and C, respectively. 
The Okinawa Trough Seismic Zone (Fig. 8) trends in the E-W direction and is situated near the axial center of the Okinawa trough at its westernmost part to the east of the Ilan plain in northeastern Taiwan. It is under tensional stress (e.g., Cheng, 1995; Kao et al., 1998), and obviously associated with the present process of the Okinawa trough formation. It is further divided into two seismic belts. The northern belt (designated by $\mathrm{N}$ in Fig. 8) is situated in the deepest part of the rough between $121.9^{\circ}$ and $122.6^{\circ} \mathrm{E}$, and the southern belt (designated by S) is along the northern slope of the Ryukyu arc between $122^{\circ}$ and $122.6^{\circ} \mathrm{E}$. Compared with the location of the central graben in Fig. 5, these two seismic belts occur separately on the western extension of the morphologically recognizable parts of the $\mathrm{N}$ and $\mathrm{S}$ graben. It is interesting that these seismic belts are situated where these graben cannot be easily distinguished from the morphological background due to sediment coverage or presence of the Ryukyu arc, and thus indicate where and how the graben develop westwards. We can conclude that the graben have been developing from the east to the west, and where the seismic belts exist are locations which are subsiding most severely to become new parts of the graben. The area of most active volcanoes observed with "black chimeys" (Tsai et al., 1998) confirms this conclusion. The northern seismic belt has extended to the Kuei-shan islet in the northeastern nearshore area of the Ilan plain (Figs. 2 and 8). To the west of the islet, the northern seismic belt is contaminated by epicenters along the NE-SW trending active fault (e.g., Tsai et al., 1975; although we do not discuss the fault systems in this paper, they play an important role in shaping the westernmost part of the Okinawa trough because they influence the pattern of subsidence). The southern seismic belt seems to stop about $30 \mathrm{~km}$ off the eastern coastline of the Ilan plain. However, the geophysical data support the idea that the formation process of the southern graben is going on further westwards. In a study of seismic tomography, Yeh et al. (1989) found an E-W trending low seismic velocity zone in the center of the Ilan plain and its eastern offshore area along the extension line of the southern graben. Yu and Tsai (1979) found a large E-W trending magnetic anomaly in the center of the Ilan plain. Liu (1995) concluded from a ten-year geodetic survey along roads in the N-S direction in the Ilan plain that the plain is subsiding with the maximal value of $2 \mathrm{~cm} / \mathrm{y}$ in the center of the plain. How the subsiding rate of the graben changes westwards with longitude and seismic activity is an intriguing question.

\subsection{Hypocentral Profiles}

Figure 9 shows three hypocentral profiles along longitudes $122.0^{\circ}, 122.4^{\circ}$ and $122.8^{\circ} \mathrm{E}$. In these profiles, there are two obvious layers of dense hypocenters. The lower layer is the Watadi-Benioff Zone associated with the northward subduction of the Philippine Sea plate beneath the Ryukyu subduction zone (including the Ryukyu trench, the Ryukyu arc and the Okinawa trough). The top layer is flat and near the surface; it corresponds to the crustal layer which fractures under tectonic stress mainly due to the subduction. These two layers of dense hypocenters stop abruptly at $25^{\circ} \mathrm{N}$, which is the northern boundary of the northern central graben of the Okinawa rough. In contrast, there is a much lower density of earthquakes to the north of $25^{\circ} \mathrm{N}$. Kao et al. (1998) studied the focal mechanisms near the western end of the Ryukyu subduction zone and found that the stress along the subducting slab is down-dip tensional between the depths of $80 \mathrm{~km}$ and $120 \mathrm{~km}$. This depth range corresponds to the area 

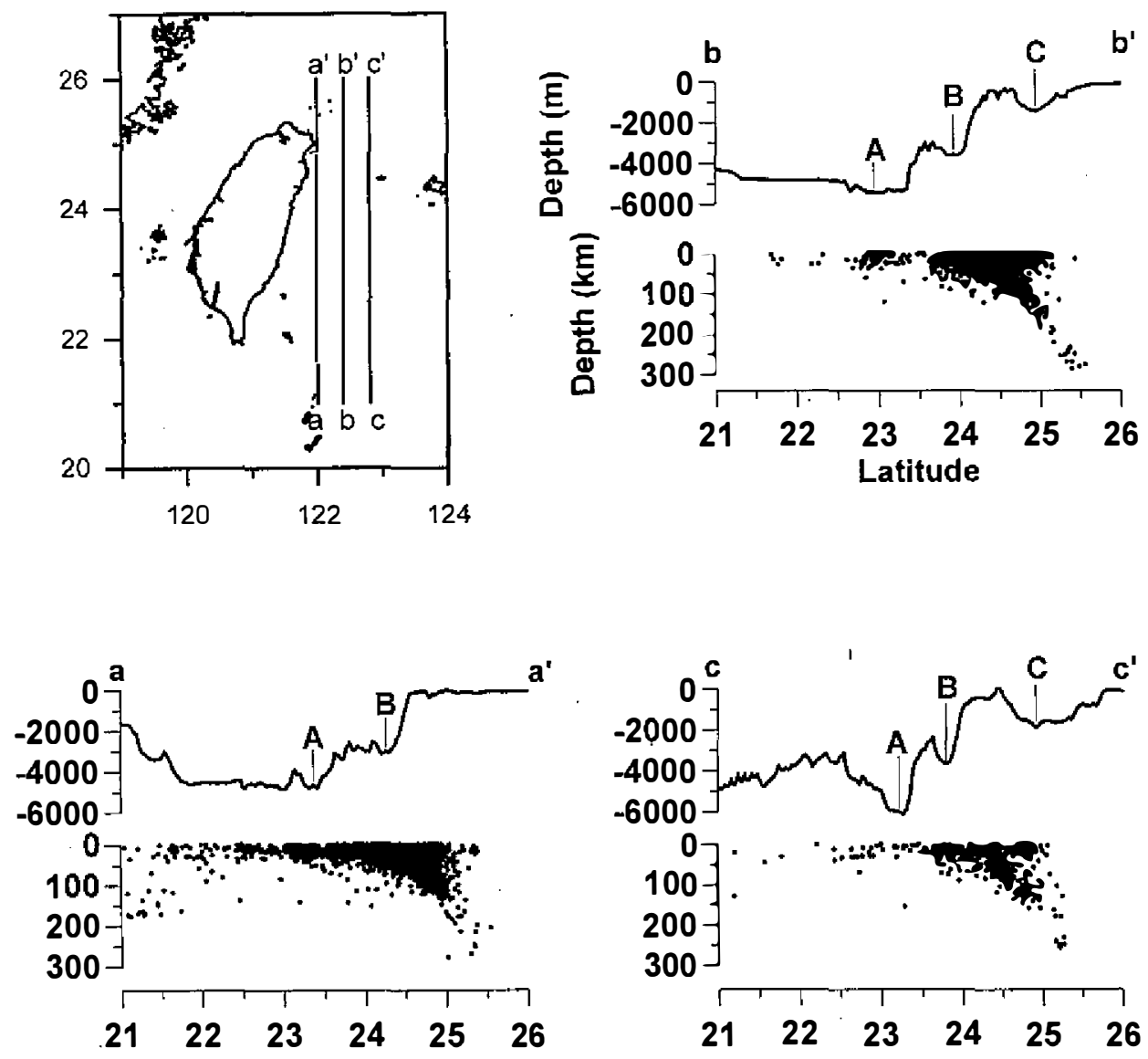

Fig. 9. The comparison of the hypocentral profiles with bathymetry in the eastern offshore area of Taiwan. The hypocenters of earthquakes shown in the profiles are within 0.1 degree on both sides of the $\mathrm{N}-\mathrm{S}$ directional lines shown on the top-left corner of the figure. A: Ryukyu trench; B: Nan-ao basin; C: Okinawa trough.

between the northern slope of the Ryukyu arc and $25^{\circ} \mathrm{N}$. It is obvious that the down-dip tensional stress causes the tensional environment in the crust for the vigorous subsiding activity which has been forming the central graben discussed above.

Kao et al. (1998) also showed a down-dip compressional focal mechanism at a depth about $270 \mathrm{~km}$, which is under Subarea $\mathrm{f}$ on the continental shelf edge (between dashed and dotted lines in Figs. 5 and 6). We believe that the stress along the subducting slab between the depths of $120 \mathrm{~km}$ and $270 \mathrm{~km}$ (i.e., between $25^{\circ}$ and $25.8^{\circ} \mathrm{N}$ ) is also down-dip tensional, because the morphology shows the tensional features. Further down from a depth of $270 \mathrm{~km}$, the stress along the subducting slab may be down-dip compressional if there is still subduction there, because the apparent subsidence stops.

Although the cause of the change in stress and seismicity still remains an intriguing ques- 
tion, we can conclude that the present formation of the westernmost part of Okinawa trough is associated with the down-dip tensional stress along the subducting slab.

\subsection{Focal Mechanisms}

In the northem Taiwan area, there exist two conflicting tectonic behaviors. The arc-continent collision (e.g., Suppe, 1984; Teng, 1990) or arc-arc collision (Hsu and Sibuet, 1995) is still occurring vigorously to build the mountains on Taiwan. The subduction of the Philippine Sea plate forms the Ryukyu subduction zone which includes the Okinawa trough whose westward extension is of interest in this paper. As concluded above, the formation of the westernmost part of the Okinawa rough is within the area between the Ryukyu arc and the continental shelf edge of the East China Sea, beneath which the stress along the subducting slab of the Philippine Sea plate is down-dip tensional. According to Wang et al. $(1994 ; 2000)$ the westem boundary of the subducting Philippine Sea plate is along $121.5^{\circ} \mathrm{E}$ beneath northern Taiwan. Thus, the formation of the Okinawa trough may be in process beneath northern Taiwan. This coincides with the suggestion by Teng (1996) that northern Taiwan provides a vivid example of the process of postorogenic collapse. We shall analyze focal mechanisms of earthquakes which occurred in northem Taiwan to understand the stress distribution in order to check the idea and status of the westward extension of the Okinawa trough.

Figures 10 and 11 show focal mechanisms of earthquakes in the southwestern Okinawa trough (Table 1) and in northern Taiwan (Table 2), respectively. These focal mechanisms were collected from the literature (Cheng, 1995; Chiang, 1994; Lin, 1987; Kao et al., 1998; Huang and Yeh, 1992; Dziewonski et al., 1989). We classified these focal mechanisms into three types according to the dip angles of the $\mathrm{P}$ and $\mathrm{T}$ axes (i.e., axes of compressional stress and dilatational stress): (1)Nomal fault type: the dip angle of the $\mathrm{T}$ axis falls between 0 and 45 degrees and that of the $\mathrm{P}$ axis between 45 and 90 degrees; (2)Thrust fault type: the dip angle of the $P$ axis falls between 0 and 45 degrees and that of the $T$ axis between 45 and 90 degrees; (3) Strike-slip fault type: those focal mechanisms that do not belong to the above two types. It is obvious that the focal mechanisms in Fig. 10 and Table I show that the central part of the Okinawa trough is under tensional stress (see Kao et al., 1998, for interpretation of focal mechanisms on the Ryukyu arc and to its south). We got the following statistics for focal mechanisms in northern Taiwan: $45 \%$ of the 52 focal mechanisms are of normal fault type; $40 \%$ are of strike-slip fault type and $15 \%$ are of thrust fault type. It is clear that most of the focal mechanisms are of normal fault and strike-slip fault types. The earthquakes of normal fault type are distributed all over northern Taiwan, especially to the north of line $\mathrm{AA}^{\prime}$ shown in Fig. 10. To the north of line $\mathrm{AA}^{\prime}$, almost all of the focal mechanisms are of the normal fault type. This indicates that the northernmost part of Taiwan is also under tensional stress, which may be caused by the extension of the formation of the Okinawa trough.

\section{DISCUSSION}

Bowin et al. (1978) proposed that the Ilan plain in northeastern Taiwan is the southwestern end of the Okinawa trough. The proposal was based on the shape and location of the plain, 
Wang et al.

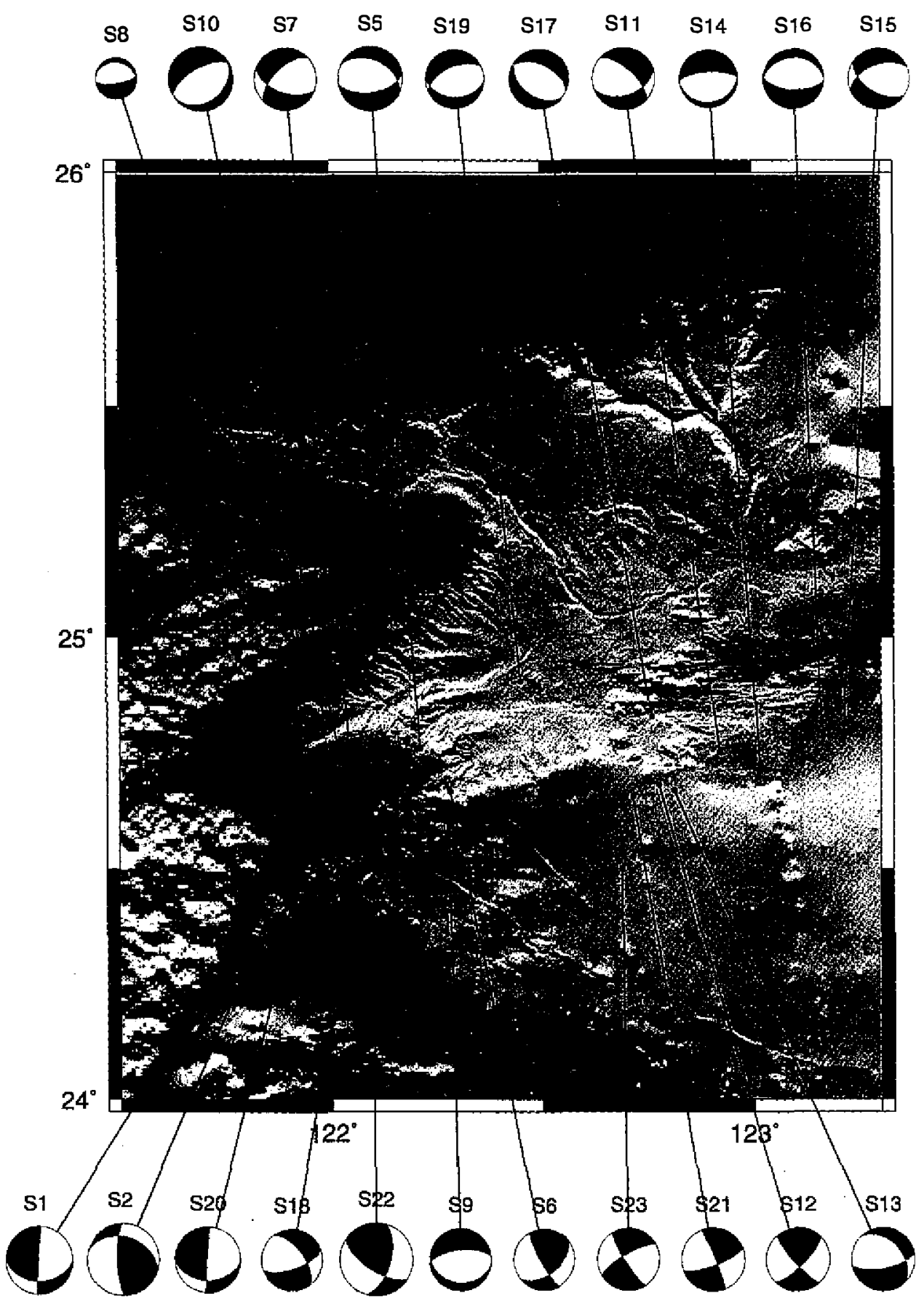

Fig. 10. Focal mechanisms of earthquakes in the western Okinawa trough (see Table 1 and text for references). Note that most of focal mechanisms in the central part of the Okinawa trough are of the normal fault type. 


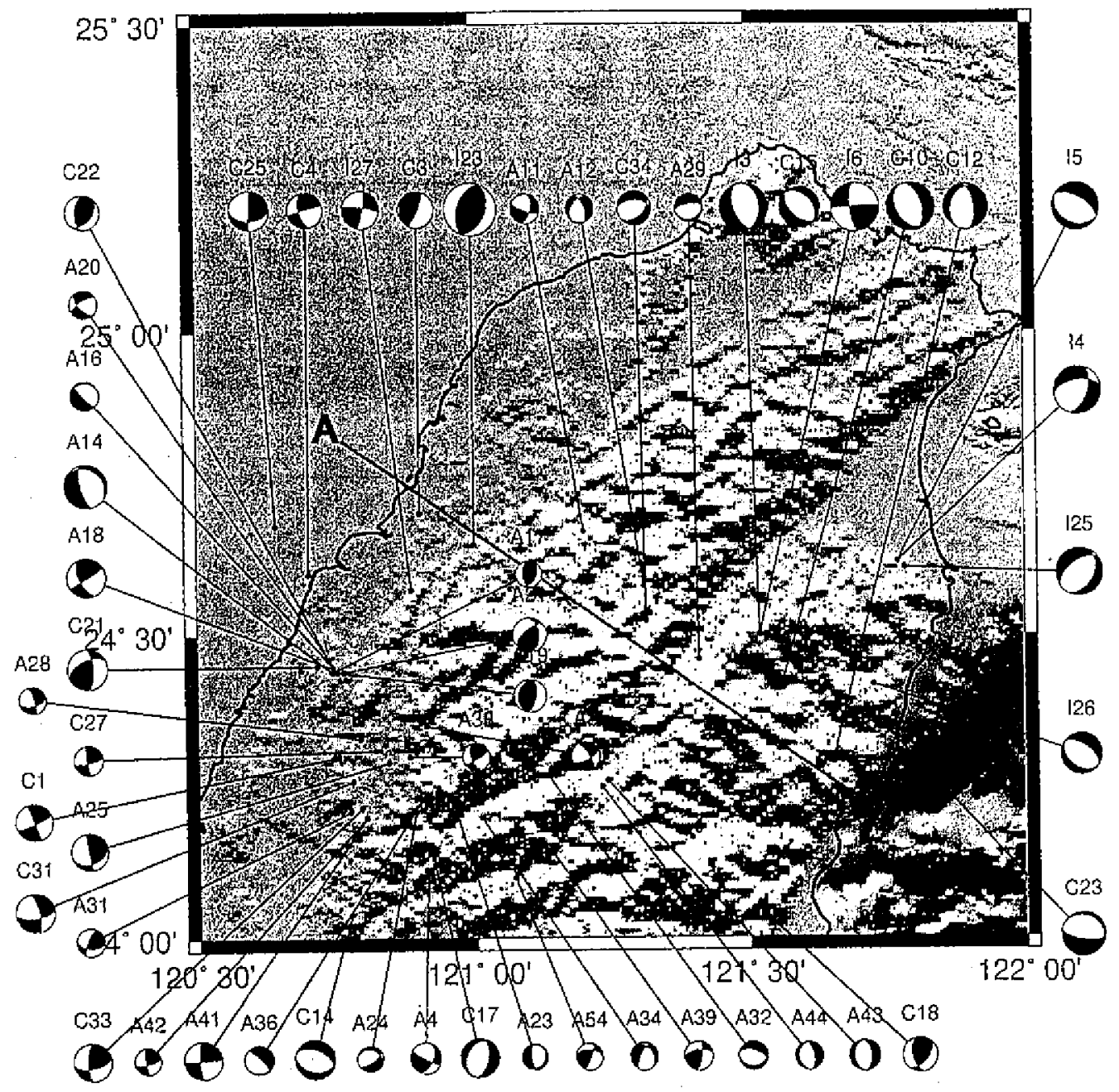

Fig. 11. Focal mechanisms of earthquakes in northern Taiwan. (see Table 2 and text for references). Note that most of the focal mechanisms are of the normal fault type and strike-slip fault type, and that most of the focal mechanisms to the north of line $\mathrm{AA}^{\prime}$ are of the normal fault type.

active faults and seismicity (Tsai et al., 1975), Quaternary age of the plain, and the continuation of acoustic basement from the trough to the plain (Lee and Lu, 1976). Since then, several researchers (e.g., Yu and Tsai, 1979; Yeh et al., 1989; Liu, 1995) have conducted geophysical surveys in the Ilan area and provided evidence for the continuation of the Okinawa trough to the Ilan plain. In this paper, we further discovered two E-W trending axial central graben in the deepest part of the westernmost portion of the Okinawa trough, which are accompanied by two narrow seismic belts of frequent shallow earthquakes and are extending westwards in the northeastern offshore and onland areas of Taiwan. Therefore, it is obvious that the western end 
of the Okinawa rough is still extending westwards and subsiding to form a new portion of the trough in the Ilan plain and its eastern offshore area.

Moreover, we found that the Ilan plain is only a part of the frontier of the westwardextending Okinawa trough. The vast area of the continental shelf edge and continental slope to the northeast of Taiwan and on the north side of the traditionally-recognized Okinawa trough is subsiding. This area of subsidence will form the northern half of the Okinawa trough and is also extending westwards. Morphology show that this area of subsidence has extended so far to $121.5^{\circ} \mathrm{E}$ ( to the north of the Tatun volcano in northern Taiwan). We therefore conclude that new portions of the Okinawa rough have been developing on its whole western frontier about $100 \mathrm{~km}$ wide, to make it extend westwards. This conclusion is coincident with the suggestion by Teng (1996) that northern Taiwan is the site of postorogenic collapse.

The result of this study makes us reconsider the origin and formation process of the southwestern part of the Okinawa trough. The simple spreading model cannot adequately explain the morphology of the western end of the Okinawa trough which is still evolving and extending westwards. Besides, according to the isotopic study of Shinjo et al. (1999), the southwestern part of the Okinawa trough is an "atypical" young intracontinental backarc basin, which may be attributed to the collision-subduction complex in the northern Taiwan area. Therefore, a comprehensive study in the future for a model of the origin and formation process of the southwestern part of the Okinawa trough is required.

Table 1. Focal mechanisms in the southwestern Okinawa.

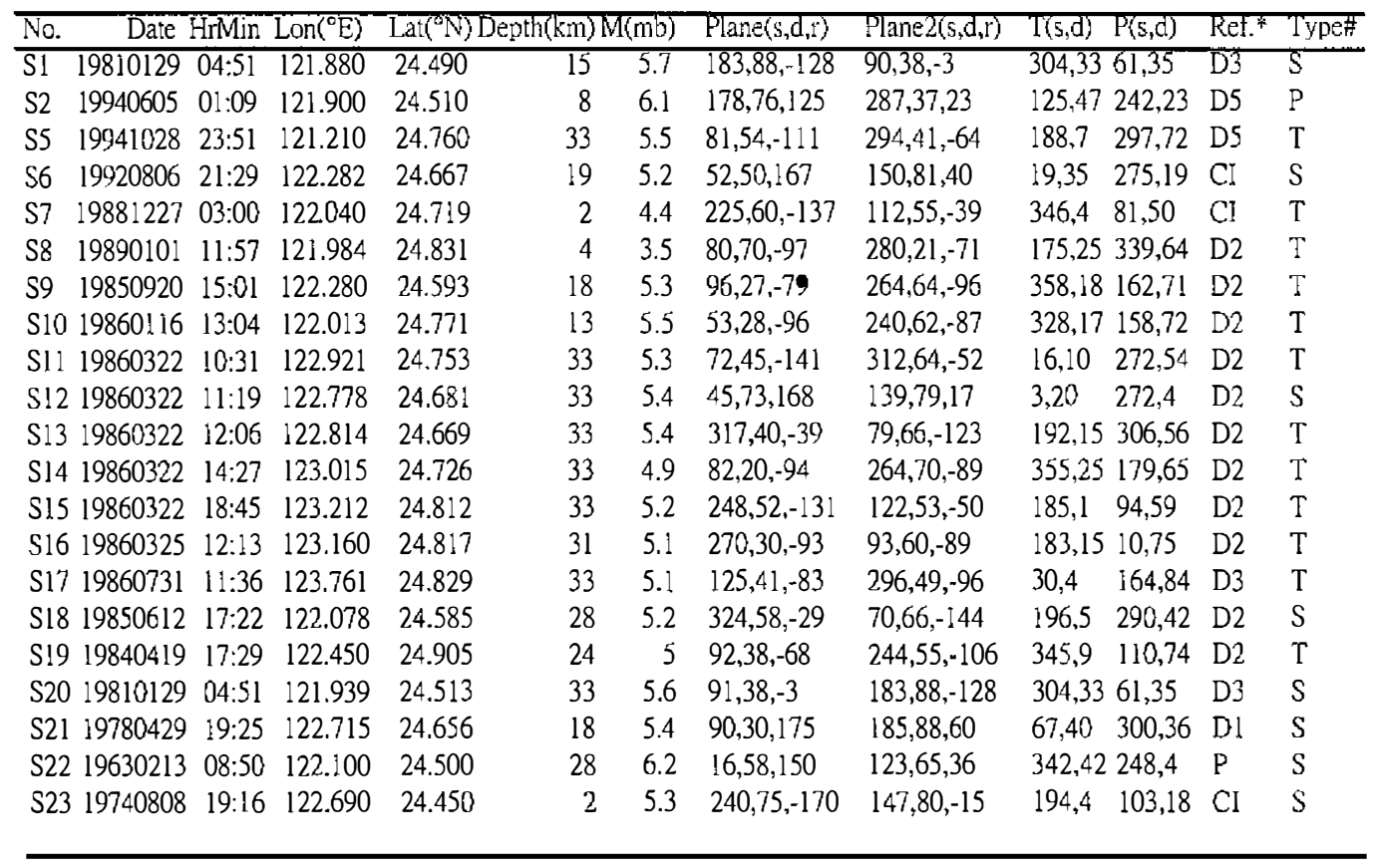

\footnotetext{
*D1: Dziewonski et al., 1981

D2: Dziewonski et al., 1987

D3: Dziewonski et al., 1988
}

\#T: Normal fault type

P: Thrust fault type

S: Strike-slip fault type 
Table 2. Focal mechanisms in the northern Taiwan.

\begin{tabular}{|c|c|c|c|c|c|c|c|c|c|}
\hline No. & $\overline{\text { Date }}$ & HrMin Lon $\left.\left({ }^{\circ} \mathrm{E}\right)\right]$ & Lat $\left(9^{\circ} N\right) I$ & $h(\mathrm{~km}) \mathrm{I}$ & (mb) Plane(s,d,r) & Plane2(s,d,r) & $T(s, d)$ & $\mathrm{P}(\mathrm{s}, \mathrm{d}) \quad \operatorname{Ref}$ & Type\# \\
\hline$\sqrt{3}$ & 19830510 & $00: 15121.520$ & 24.50 & 7.0 & $5.6159,55 .-100$ & $356,36,-76$ & 256,10 & $36.77 \mathrm{~K}$ & $\mathrm{~T}$ \\
\hline I4 & 19860630 & $11: 31121.770$ & 24.62 & 14.0 & $5.619,56,-136$ & $261,55,-43$ & 140,0 & $230,53 \mathrm{~K}$ & $\mathrm{~T}$ \\
\hline I5 & 19860630 & $11: 31121.770$ & 24.62 & 20.0 & $5.6114,31,-95$ & $300,59,-87$ & 28,14 & $219,76 \mathrm{~K}$ & $\mathrm{~T}$ \\
\hline !6 & 19830510 & $00: 15121.520$ & 24.50 & 30.0 & $5.6 \quad 174,72,177$ & $265,87,18$ & 131,15 & $38,11 \mathrm{~K}$ & $s$ \\
\hline I23 & 19350420 & $22: 02121.000$ & 24.65 & 9.0 & $6.2200,50,90$ & $20,40,90$ & 110,85 & $290,5 \quad \mathrm{H}$ & $\mathrm{P}$ \\
\hline$I 25$ & 19860730 & $11: 31 \quad 121.782$ & 24.61 & 33.0 & $5.627,40,-111$ & $234,53,-73$ & 312,7 & 196,75 D3 & $\mathrm{T}$ \\
\hline I26 & 19871110 & $04: 33121.724$ & 24.42 & 34.0 & $4,9125,35,-90$ & $305,55,-90$ & 35,10 & $215,80 \mathrm{CE}$ & $\mathrm{T}$ \\
\hline $\mathrm{I} 27$ & 19910120 & $17: 42120.885$ & 24.58 & 7.0 & $4,310,80,10$ & $278,80,170$ & 234,14 & $324,0 \quad \mathrm{CE}$ & $S$ \\
\hline A3 & 19910819 & $06: 14120.910$ & 24.35 & 26.0 & $3.3326,71,-24$ & $64,67,-160$ & 16,3 & $284,30 \mathrm{CI}$ & S \\
\hline A4 & 19910819 & $10: 44120.910$ & 24.11 & 37.0 & $3,822,51,-8$ & $116,84,-140$ & 243,22 & $348,32 \cdot \mathrm{CI}$ & $S$ \\
\hline Al! & 19920227 & $11: 45121.200$ & 24.67 & 9.4 & $3.412,59,-16$ & $110,76,-148$ & 238,11 & $336,33 \mathrm{CI}$ & S \\
\hline Al2 & 19920320 & $21: 12121.310$ & 24.58 & 5.9 & $3215,41,-41$ & $338,64,-123$ & 92,13 & $202,57 \mathrm{CI}$ & $\uparrow$ \\
\hline Al4 & 19920320 & $16: 16120.740$ & 24.44 & 11.2 & $5.2165,71,-74$ & $304,25,-129$ & 243,24 & $98,61 \quad \mathrm{CI}$ & $T$ \\
\hline A16 & 19920420 & $16: 33120.750$ & 24.44 & 11.0 & 3.5136 & $259,18,-146$ & 213,34 & $64,52 \quad \mathrm{CI}$ & $T$ \\
\hline A17 & 19920420 & $16: 48120.740$ & 24.44 & 11.2 & $3.4178,52,71$ & $27,42,113$ & 29,74 & $282,5 \quad \mathrm{CI}$ & $P$ \\
\hline A.18 & 19920421 & $13: 36120.760$ & 24.44 & 11.9 & $4.6152,61,6$ & $60,86,150$ & 11,24 & $109,17 \mathrm{CI}$ & S \\
\hline A.19 & 19920422 & $07: 55120.750$ & 24.44 & 10.6 & $3.910,60,90$ & $190,30,90$ & 280,75 & $100,15 \mathrm{CI}$ & $P$ \\
\hline A.20 & 19920422 & $19: 59120.750$ & 24.44 & 11.1 & $3.3137,64,-24$ & $238,69,-152$ & 6,3 & $98,35 \mathrm{CI}$ & S \\
\hline A.2! & 19920426 & $13: 59120.760$ & 24.44 & 11.0 & 3.9354 & $231,65,123$ & 187,57 & $297.13 \mathrm{CI}$ & $P$ \\
\hline A.23 & 19920618 & $20: 18120.960$ & 24.22 & 31.0 & $3.135,2$ & $174,71,-106$ & 277,24 & $61,61 \mathrm{Cl}$ & $\mathrm{T}$ \\
\hline A.24 & 19920917 & $10: 41120.890$ & 24.21 & 13.5 & $3.1289,35,-42$ & $53,69,-116$ & 165,18 & $287,58 \mathrm{CI}$ & $\mathrm{T}$ \\
\hline A.25 & 19921216 & $12: 29120.840$ & 24.29 & 27.7 & $4.4168,86,55$ & $72,35,173$ & 46,39 & $287,32 \mathrm{Cl}$ & S \\
\hline A28 & 19930120 & $20: 2 ! 120.790$ & 24.33 & 12.7 & $3.2342,81 .-34$ & $78,55,-171$ & 34,17 & $294,30 \mathrm{CI}$ & S \\
\hline A29 & 19930122 & $04: 51121.410$ & 24.46 & 7.3 & 3.3262 & $68,21,-103$ & 348,25 & $181,65 \mathrm{CI}$ & $\mathrm{T}$ \\
\hline A31 & 19930208 & $22: 35 \quad 120.770$ & 24.21 & 23.0 & 3.3201 & $95,48,159$ & 66,42 & $323.14 \mathrm{CI}$ & $S$ \\
\hline A32 & 19930319 & $02: 50120.130$ & 24.27 & 9.7 & $3.5287,61,-78$ & $83,31,-111$ & 9.15 & $224,72 \mathrm{CI}$ & $\mathrm{T}$ \\
\hline A33 & 19930327 & $14: 08120.880$ & 24.30 & 31.0 & 3.2159 & $61,76,148$ & 16,33 & $113,11 \mathrm{CI}$ & S \\
\hline A34 & 19930504 & $11: 16121.010$ & 24.20 & 36.0 & 3.3205 & $325,38,-144$ & 271,17 & $156,54 \mathrm{Cl}$ & $\mathrm{T}$ \\
\hline A36 & 19930602 & $10: 58120.900$ & 24.23 & 28.2 & $3.4313 .85 .-80$ & $69.11,-153$ & 34,39 & $234.49 \mathrm{Cl}$ & $\mathrm{T}$ \\
\hline A39 & 19931011 & $12: 26121.140$ & 24.14 & 42.0 & $3.57,71,36$ & $263,55,158$ & 231,38 & $133,10 \mathrm{Cl}$ & $S$ \\
\hline A4l & 19931213 & $09: 23120.800$ & 24.20 & 23.4 & $4.5177,76,5$ & $86,85,166$ & 41,14 & $132,6 \mathrm{Cl}$ & $S$ \\
\hline A42 & 19931213 & $09: 25120.800$ & 24.20 & 22.7 & $3.2172,76,21$ & $77,69,166$ & 35.25 & 303,4 CI & $S$ \\
\hline A43 & 19940210 & $20: 54121.240$ & 24.26 & 7.5 & 3.7355 & $175,35,-90$ & 85,10 & $265,80 \mathrm{CI}$ & $\mathrm{T}$ \\
\hline A44 & 19940210 & $20: 55121.230$ & 24.25 & 8.3 & $3.3179,30,-80$ & $347,61,-96$ & 81,15 & $242,74 \mathrm{CI}$ & $\mathrm{T}$ \\
\hline A54 & 19940629 & $03: 26121.070$ & 24.10 & 40.0 & $3.1618,79,44$ & $277,47,165$ & 247,38 & $140,21 \mathrm{CI}$ & $S$ \\
\hline $\mathrm{Cl}$ & 19350420 & $22:, 02120.750$ & 24.30 & 3.0 & $4.367 .80,180$ & $337,90,-10$ & 22,7 & $292,7 \quad \mathrm{~L}$ & S \\
\hline C3 & 19350420 & $22: 26120.900$ & 24.70 & 2.0 & $4.2203,10,90$ & $23,80,90$ & 293,55 & $113,35 \mathrm{~L}$ & P \\
\hline $\mathrm{C} 4$ & 19350717 & $00: 19120.700$ & 24.60 & 30.0 & $4.1165,60,0$ & $75,90,150$ & 26,21 & $124,21 \mathrm{H}$ & $\mathrm{S}$ \\
\hline $\mathrm{ClO}$ & 19830510 & $00: 15121.560$ & 24.42 & 28.0 & $5.6150,40,-100$ & $343,51,-82$ & 67,5 & 298,81 D2 & $\mathrm{T}$ \\
\hline $\mathrm{Cl} 2$ & 19870627 & $07: 32121.650$ & 24.29 & 27.0 & $5.2201,33,-64$ & $351,61,-106$ & 93,14 & 227.70 D3 & $\mathrm{T}$ \\
\hline $\mathrm{Cl} 4$ & 19880408 & $13: 34120.771$ & 24.04 & 33.0 & $4.7100,38,-100$ & $293,53,-82$ & 17,7 & $237,80 \mathrm{D} 4$ & $\mathrm{~T}$ \\
\hline $\mathrm{Cl} 5$ & 19880703 & $05: 20121.570$ & 25.16 & 5.0 & $4.7135,52,-90$ & $315,38,-90$ & 225,7 & $45,83 \mathrm{Cl}$ & $\mathrm{T}$ \\
\hline $\mathrm{Cl7}$ & 19890321 & $17: 53120.920$ & 24.13 & 23.0 & $4.6310,55,-100$ & $207,36,-76$ & 107,9 & $246,77 \mathrm{CI}$ & $\mathrm{T}$ \\
\hline $\mathrm{C} 18$ & 19910422 & $07: 42121.535$ & 24.03 & 23.0 & $4.140,5$ & $167,54,53$ & 17,60 & $283,2 \quad \mathrm{CI}$ & $\mathrm{P}$ \\
\hline $\mathrm{C} 2 \mathrm{I}$ & 19920420 & $16: 16120.714$ & 24.45 & 9.0 & $4.8355,65,40$ & $245,54,149$ & 215,45 & $118,6 \quad \mathrm{Cl}$ & $\mathrm{P}$ \\
\hline $\mathrm{C} 22$ & 19920429 & $16: 54120.734$ & 24.46 & 11.0 & $4.141,40,120$ & $184,56,67$ & 43,69 & $290,9 \mathrm{CI}$ & $P$ \\
\hline $\mathrm{C} 23$ & 19920806 & $16: 49121.725$ & 24.34 & 48.0 & $5.2300,20,-70$ & $99,71,-97$ & 194,26 & $358,63 \mathrm{CI}$ & $T$ \\
\hline $\mathrm{C} 25$ & 19921020 & $07: 08120.640$ & 24.68 & 7.0 & $4.690,45,179$ & $181,89,45$ & 55,31 & $306,29 \mathrm{CI}$ & S \\
\hline $\mathrm{C} 27$ & 19921216 & $12: 29120.817$ & 24.31 & 34.0 & $3.5170,80,15$ & $77,75,170$ & 34,18 & $303,3 \quad \mathrm{CI}$ & $S$ \\
\hline C31 & 19930207 & $20: 19120.776$ & 24.26 & 28.0 & $4.6345,73,-25$ & $83,66,-161$ & 35,5 & $302,30 \mathrm{CI}$ & S \\
\hline C33 & 19931213 & $09: 23120.719$ & 24.22 & 26.0 & $4.5180,70,30$ & $79,62,158$ & 42,35 & $308,5 \quad \mathrm{CI}$ & $S$ \\
\hline C34 & 19930502 & $15: 27121.314$ & 24.52 & 42.0 & $450,45,-120$ & $269,52,-63$ & 341,4 & $241,69 \mathrm{CI}$ & $\mathrm{T}$ \\
\hline \multicolumn{3}{|c|}{ "D2: Dziewonski et a1.. 1987} & \multicolumn{3}{|c|}{ CE:Cheng, 1995} & \multicolumn{4}{|l|}{ L: $\operatorname{Lin}, 1987$} \\
\hline \multicolumn{3}{|c|}{$\begin{array}{l}\text { D3: Dziewonski et al., } 1988 \\
\text { D4: Dziewonski et al., } 1989\end{array}$} & \multicolumn{3}{|c|}{ CI: Ciang, 1994} & \multicolumn{4}{|c|}{$\#$ T: Normal fault type } \\
\hline & : Dziewons & ki et al., 1989 & \multicolumn{3}{|c|}{ K: Kao et al., 1998} & \multicolumn{4}{|c|}{ P: Thrust fault type } \\
\hline \multicolumn{3}{|c|}{ D5: Dziewonski et al., 1995} & \multicolumn{3}{|c|}{ H: Huang and Yeh, 1992} & \multicolumn{4}{|c|}{ S: Strike-slip fault type } \\
\hline
\end{tabular}


The Kuroshio (or Taiwan) current passes through the northeastern offshore area of Taiwan. The question of its effect on morphological features described in this paper has thus been raised. The Kuroshio flows northwards along the eastern coast of Taiwan. After it passes through a saddle of the Ryukyu arc between Taiwan and Yonaguni Tima (Fig. 2) and arrives at the Okinawa trough near the Ilan plain in northern Taiwan, it gradually turns its course to the northeast direction along the Okinawa trough, mainly due to the blockage of the continental slope of the East China Sea. Liu et al. (1998) measured the velocity structure and volume transport of the Kuroshio east of Taiwan mainly along the westernmost part of the Ryukyu arc during the period from 1990 to 1996, and found that the strongest current velocity of the Kuroshio off the Ilan plain is between $122^{\circ}$ and $122.5^{\circ} \mathrm{E}$. Thus, if there were any significant effect on the morphological features, it would be between these longitudes. However, this effect is not noticeable in Fig. 5. Therefore, the effect of the Kuroshio on the morphological features is negligible, and all the morphological features discussed in this paper are mainly tectonic.

\section{CONCLUSIONS}

We have analyzed the morphology, seismicity and focal mechanisms of earthquakes in the northeastern offshore and onland areas of Taiwan to understand the phenomenon and behavior of the active westward extension of the Okinawa trough at its western end, and obtained the following conclusions:

1. We found a distinguishable area of subsidence situated on the continental shelf edge and continental slope, which will become the northern half of the Okinawa trough. It contains several morphological units with different degrees of development which indicates that the Okinawa trough has been developing from the east to the west at its westernmost part. These morphological units are still evolving mainly through subsiding and collapsing of material, and demonstrate how new portions of the northern half of the Okinawa trough have been forming.

2. Two central graben to the east of the Ilan plain were found in the central and deepest area of the Okinawa trough. Although the eastern halves of the graben have been better developed morphologically than the western halves, the latter are more active tectonically than the former in terms of the seismic and thermal activities. The graben have developed gradually under tensional stress, and are still extending westwards in the northeastern offshore and onland areas of Taiwan.

3. Focal mechanisms of earthquakes and morphology show that the whole northeastern onland and offshore areas of Taiwan are under tensional stress and are subsiding to form new portions of the Okinawa trough. If the area of subsidence on the continental shelf edge and the continental slope is tectonically considered as a part of the Okinawa trough, then the width the Okinawa trough is approximately uniform for its whole westernmost part. This implies that the Okinawa rough extends westwards through subsidence and collapse on the whole frontier of its western end, which is about $100 \mathrm{~km}$ in width.

4. The tensional stress and the subsidence in the westernmost part of the Okinawa trough are 
caused by the down-dip extensional stress along the northward-subducting slab of the Philippine Sea plate between the northern slope of the Ryukyu arc and the continental shelf edge of the East China Sea.

Acknowledgements This study is supported by the National Science Council of the Republic of China (Taiwan). We would like to express our sincere thanks to Professor Serge Lallemand ( Université Montpellier II, France) and Professor Char-shine Liu ( National Taiwan University), Chief Scientists of the ACT cruise, for permission to use part of the data collected on the ACT cruise. We are also grateful to the Seismological Observation Center, Central Weather Bureau, Ministry of Transportation of the Republic of China (Taiwan) for providing us with the seismicity data used in this study. We would also like to thank Professor Jean-Claude Sibuet (IFREMER: Institut Francais de Recherche pour l'Exploitation de la mer, France) and Dr. Shu-Kun Hsu (National Central University, Taiwan) for making the bathymetric data of the Okinawa trough available, and Dr. Gwo-Shyh Song (National Taiwan University) for the useful bathymeric data collected in his many cruises for the KEEP program.

\section{REFERENCES}

Bowin, C., R. S. Lu, C. S. Lee, and S. W. Roecker, 1989: Plate convergence and accretion in Taiwan-Luzon region. A.A.P.G., 62, 1645-1672.

Cheng, S. N., 1995: The study of stress distribution in and around Taiwan, PhD. thesis, National Central University (Taiwan).

Chiang, C. H., 1994: A study of tectonic stress and strain estimated from focal mechanisms of earthquakes in the Taiwan region, MSc thesis, Institute of Oceanography, National Taiwan University (in Chinese).

Dziewonski, A. M., T. A. Chou, and J. H. Woodhouse, 1981: Determination of earthquake source parameters from waveform data for studies of global and regional seismicity. $J$. Geophys. Res., 86, 2825-2852.

Dziewonski, A. M., G. Ekstrom, J. E. Franzen, and J. H. Woodhouse, 1987: Centroid-moment tensor solutions for January-March 1986. Phys. Earth Planet. Inter., 45, 1-10.

Dziewonski, A. M., G. Ekstrom, J. E. Franzen, and J. H. Woodhouse, 1988: Global seismicity of 1981: Centroid-moment tensor solutions for 542 earthquakes. Phys. Earth Planet. Inter., 50, 155-182.

Dziewonski, A. M., M. G. Ekstrom, J. H. Woodhouse, and G. Zwart, 1989: Centroid-moment tensor solutions for April-June, 1988. Phys. Earth Planet. Inter., 54, 187-201.

Dziewonski, A. M., G. Ekstrom, and M. P. Salganik, 1995: Centroid-moment tensor solutions for October-December, 1994. Phys. Earth Planet. Inter., 91, 155-182.

Ho, C. S., 1988: An introduction to the geology of Taiwan, 2nd ed., 192 pp., Central Geological Survey, The Ministry of Economic Affairs, Taipei (in Chinese).

Hsu, S. K., and J.-C. Sibuet, 1995: Is Taiwan the result of arc-continent or arc-arc collision?. Earth Planet. Sci. Lett., 136, 315-324.

Hsu, S. K., J.-C. Sibuet, S. Monti, C. T. Shyu, and C. S. Liu, 1996: Transition between the Okinawa rough backarc extension and the Taiwan collision: New insights on the south- 
ernmost Ryukyu subduction zone. Marine Geophys. Res., 18, 163-187.

Huang, B. S., and Y. T. Yeh, 1992: Source geometry and slip distribution of April 21, 1935, Hsinchu-Taichung, Taiwan earthquake. Tectonophysics, 210, 77-90.

Huang, S. T., H. H. Ting, R. C. Chen, W. R. Chi, C. C. Hu, and H. C. Shen, 1992: Basinal framework and tectonic evolution of offshore northern Taiwan. Petro. Geol. Taiwan, 27, 47-72.

Kao, H., S. J. Shen, and K. F. Ma, 1998: Transition from oblique subduction to collision: Earthquakes in the southernmost Ryukyu arc -Taiwan region. J. Geophys. Res., 103, 7211-7229.

Lallemand, S. E., C. S. Liu, J. Angelier, J. Y. Collot, B. Deffontaines, S. Dominguez,. M. Foumier, S. K. Hsu, J. P. Le Formal, S. Y. Liu, C. Y. Lu, J. Malavieille, P. Schnürle, J.C. Sibuet, N. Thareau, and C. Wang, 1996: ACT cruise report, Instituts National des Sciences de l'Univers.

Lee, C. S., and R. S. Lu, 1976: Significance of the southwestern section of Ryukyu Inner Ridge in the exploration of geothermal resource in Ilan area, Mining Technology, Taiwan, 15, 117-140.

Lee, C..S., Jr. G.. G. Shor, L. D. Bibce, R. S. Lu, and T. W. C. Hilde, 1980: Okinawa Trough: origin of a back-arc basin. Mar. Geol., 35, 219-241.

Lin, T. H., 1987: Focal mechanism of the disastrous 1935 Hsinchu-Taichung earthquake, MSc thesis, Institute of Geophysics, National Central University (in Chinese).

Liu, C..C., 1995: The Ilan plain and the southwestward extending Okinawa trough. J. Geol. Soc. China. 38, 229-242.

Liu, C. S., S. Y. Liu, G. S. Song, C. T. Shyu, H. S. Yu, L. Y. Chiaw, and C. Wang, 1996: Digital morphological file of the offshore region around Taiwan, Collection of Abstracts of Annual Meeting of Geological Society of China. 420-425 (in Chinese).

Liu, C. T., S. P. Cheng, W. S. Chuang, Y. Yang, T. N. Lee, W. E. Johns, and H. W. Li, 1998: Mean structure and transport of Taiwan Current (Kuroshio), Acta Oceanographica Taiwanica, 36, 159-176.

Pezzopane, S. K., and S. G. Wesnonsky, 1989: Large earthquakes and crustal deformation near Taiwan. J. Geophys. Res., 97, 11749-11759.

Shinjo, R., S. L. Chung, Y. Kato, and M. Kimura, 1999: Geochemical and Sr-Nd isotopic characteristics of volcanic rocks from the Okinawa trough and Ryukyu arc: Implications for the evolution of a young, intracontinental backarc basin. J. Geophys. Res., 104, 10591-10608.

Sibuet, J.-C., B. Deffontaines, S. K. Hsu, N. Thareau, J.-P. Le Formal, C. S. Liu, and ACT party, 1998: Okinawa trough backarc basin: Early tectonic and magmatic evolution. $J$. Geophys. Res. 103, 30245-30267.

Shinjo, R., S. L. Chung, Y. Kato, and M. Kimura, 1999: Geochemical and Sr-Nd isotopic characteristics of volcanic rocks from the Okinawa trough and Ryukyu arc: Implications for the evolution of a young, intracontinental backarc basin. J. Geophys. Res., 104, 10591-10608.

Song, G. S., and Y. C. Chang, 1993: Comment on "Naming of the submarine canyons off northeastern Taiwan" by Ho-shing Yu, 1992. Acta Oceanogr. Taiwanica. 30, 77-84. 
Song, G. S., Y. C. Chang, and C. P. Ma, 1997: Characteristics of submarine topography off northern Taiwan. TAO, 8, 461-480.

Suppe, J., 1984: Kinematic of arc-continent collision, flipping of subduction, and back-arc spreading near Taiwan. Memoir Geol. Soc. China, 6, 21-33.

Teng, L. S., 1990: Geotectonic evolution of late Cenozoic arc-continent collision. Tectonophysics, 183, 57-76.

Teng, L. S., 1996: Extensional collapse of the northern Taiwan mountain belt. Geology, 24, 949-952.

Teng, L. S., 1998: A comprehensive study of the geological structure in the northeastern onland and offshore areas of Taiwan, Workshop for Oceanographic Research Programs supported by National Science Council (Taiwan), 133-137 (in Chinese).

Tsai, C. H., C. S. Lee, and C. Wang, 1998: New discovery of submarine volcanoes in the westernmost part of the Okinawa trough, Workshop for Oceanographic Research Programs supported by National Science Council (Taiwan), p.127.

Tsai, Y.B., C.C. Feng, J.M. Chiu, and H.B. Liaw, 1975: Correlation between microearthquakes and geologic faults in the Hsintien-Ilan area, Petrol. Geol. Taiwan, 12, 149-167.

Wang, C., H. F. Huang, J. T. Shin, Y. L. Liu, Y. M. Wu, H. Y. Yen, and W.C. Liang, 1994: A study of distribution pattern of earthquakes occurred during 1991-1993 in the Taiwan region, Technical Report of Seismological Observation Center, Ministry of Communication (Taipei, Taiwan), 8-1: 243-271 (in Chinese).

Wang C., M. L. Yang, C. P. Chou, W. B. Cheng, and C. S. Lee, 2000. Structure of Philippine Sea plate beneath the western end of Ryukyu subduction zone accounting for the westward extension of Okinawa trough. Tectonics (revised).

Wang, K. L., S. L. Chung, C. H. Chen, R. Shinjo, T. F. Yang, and C. H. Chen, 1999: Postcollisional magmatism around northern Taiwan and its relation with opening of the Okinawa trough. Tectonophysics, 308, 363-376.

Yeh, Y. H., C. H. Lin, and S. W. Roecker, 1989: A study of upper crustal structures beneath northeastern Taiwan: Possible evidence of the western extension of Okinawa Trough, Proc. Geol. Soc. China, 32-2, 139-156.

$\mathrm{Yu}, \mathrm{H}$. S., 1992: Naming of the submarine canyons off northeastern Taiwan. Acta Oceanogr. Taiwanica., 29, 107-122.

Yu, H. S., and C. T. Shyu, 1994: Topography, geomagnetism and structure in the shelf-slope region off northeastern Taiwan. J. Geologic. Soc. China, 37, 247-260.

Yu. H. S., and M. L. Lee, 1998: Morphological and seismic characteristics of the North Mienhua submarine canyon off northeastern Taiwan, Terrestrial. Atmospheric and Ocean Sciences, 9, 263-278.

Yu, S. B., and Y. B. Tsai, 1979: Geomagnetic anomalies of the Ilan plain, Taiwan. Petroleum Geology of Taiwan, 16, 19-27. 